\title{
A Nightmare or a Noble Dream? Establishing Investor Obligations Through Treaty-Making and Treaty-Application
}

\author{
Markus KRAJEWSKI
}

\begin{abstract}
This article assesses different approaches currently discussed and developed in international human rights and investment law to establish investor obligations. The article begins with a general framework of analysing and comparing these approaches. Next, attempts to include direct obligations of business entities in international human rights treaties are discussed. Despite earlier indications the recent initiative to create a legally binding instrument on business and human rights will most likely not include direct obligations for business entities. Subsequently, the article assesses the development of investor obligations in new international investment treaties and through the interpretation and application of existing international investment agreements. Arguably, the former will not lead to binding obligations in the foreseeable future and the latter rests on methodologically questionable grounds. Consequently, the article suggests that the way forward will require domestic legislation in host and home states to establish investor obligations which can be taken into account when interpreting existing investment treaty clauses requiring the investor to adhere to domestic law. This would reflect recent trends both in investment law reforms as well as the business and human rights movement.
\end{abstract}

Keywords: Investor obligations, investment treaties, investment arbitration, legally binding instrument

'Under international law of investments [...] investors enjoy by themselves a number of rights $[\ldots]$. What about the investor's obligations arising of the investment according to international law? ${ }^{1}$

\footnotetext{
* School of Law, Friedrich-Alexander-University of Erlangen-Nürnberg, Germany. The author declares no conflict of interest. This contribution partly builds on earlier work including a keynote address at the Frankfurt Investment Law Workshop 2018 on 'International Investment Law and Constitutional Law' and a chapter entitled 'Human Rights in International Investment Law: Recent Trends in Arbitration and Treaty-Making Practice' in the Yearbook on International Investment Law and Policy 2017.

1 David R Aven and Others $v$ Republic of Costa Rica, ICSID Case No. UNCT/15/3, Final Award, 18 September 2018, para 739
} 


\section{INTRODUCTION}

The international law protecting foreign investment contains substantive and procedural rights for investors, but hardly any obligations. This one-sidedness of a legal regime which only entrusts rights, but imposes no duties on powerful economic actors, in particular multinational enterprises, contributes to its ongoing legitimacy crisis ${ }^{2}$ prompting calls for a rebalancing of international investment law. ${ }^{3}$ Such calls have not only been voiced by academia and civil society, but increasingly by the investment law community, including investment tribunals as the above-mentioned quote of the recent decision of the tribunal in the matter Aven v Costa Rica aptly demonstrates. ${ }^{4}$

In many cases, calls for investor obligations have been framed in human rights language linking the idea of investor obligations to duties of economic actors to respect human rights. ${ }^{5}$ This is where the debates on the reform of the investment regime and on business and human rights meet. For international investment law, one element of its reform could include direct obligations of investors to observe national and international laws, including human rights. ${ }^{6}$ For human rights law, the expectation that business entities should not cause or contribute to adverse impacts of human rights is part of the second pillar of the United Nations Guiding Principles (UNGPs) on Business and Human Rights, the corporate responsibility to respect human rights. ${ }^{7}$ Investor obligations could therefore contribute to the rebalancing of international investment law and to the implementation of the UNGPs. In addition, they could go beyond the mere corporate responsibility to respect human rights and establish binding legal obligations for businesses to do so.

Whether the lack of investor obligations in international investment law is considered the investment regime's cardinal failure or the logical consequence of the vulnerability of foreign investors, remains fiercely debated. Regardless of one's position in this debate, recent developments in treaty-making and treaty-application suggest that there is a growing demand to recognize the misconduct of foreign investors, including their involvement in human rights violations, in international law generally and

\footnotetext{
2 For an early assessment focusing on divergent jurisprudence see Susan Frank, 'The Legitimacy Crisis in Investment Treaty Arbitration: Privatizing Public International Law Through Inconsistent Decisions' (2005) 73 Fordham Law Review 1521. More recently David Schneiderman, 'Legitimacy and Reflexivity in International Investment Arbitration: A New Self-Restraint?' (2011) 2 Journal of International Dispute Settlement 471 and Jane Kelsey, 'The Crisis of Legitimacy in International Investment Agreements and Investor-State Dispute Settlement' in Richard Ekins and Graham Gee (eds.), Judicial Power and the Left (London: Policy Exchange, 2017) 97. See also UNCTAD, World Investment Report 2012 - Towards a New Generation of Investment Policies (Geneva: UNCTAD, 2012), p xxi noting a 'broader public discourse about the usefulness and legitimacy of the ISDS mechanism'.

3 Steffen Hindelang and Markus Krajewski (eds.), Shifting Paradigms in International Investment Law - More Balanced, Less Isolated, Increasingly Diversified (Oxford: Oxford University Press, 2016).

4 On this case, see section IV.B.3 below.

5 Patrick Dumberry and Gabrielle Dumas-Aubin, 'How to Impose Human Rights Obligations on Corporations under Investment Treaties?' (2011-2012) 4 Yearbook on International Investment Law and Policy 569.

6 UNCTAD, Investment Policy Framework for Sustainable Development (Geneva: UNCTAD, 2015) 109.

7 Office of the High Commissioner for Human Rights, United Nations Guiding Principles on Business and Human rights (Geneva: 2011).
} 
international investment law specifically. This demand can be met by including investor obligations explicitly in new treaties or by deriving them from existing treaties through treaty interpretation.

Drafting and adopting new treaties may seem preferable from the perspective of legal clarity and security while often practically and politically difficult. Interpreting existing treaties in new and sometimes surprising ways may lead to legal innovations which would have been difficult if not impossible to legislate. Yet, despite the invaluable contribution of progressive case law, deriving new legal principles without an explicit basis in legal instruments may seem problematic from a methodological and legal philosophical perspective.

H.L.A. Hart addressed the dilemma between innovative interpretation of existing law and creation of new law through jurisprudence in 1977 with the figurative dichotomy of the nightmare and the noble dream. ${ }^{8}$ Hart noticed the enormous power of US courts in not only applying, but also 'making law'. In particular, he pointed to the US Supreme Court and its many 'legal inventions', asking how these can be reconciled with general principles of jurisprudence. ${ }^{9}$ On the one side, Hart seemed to fear that law-making judges could become a 'nightmare'. ${ }^{10}$ On the other side, he was also hoping that judges could be pursuing the 'noble dream' of an application of the law which was not driven by judicial activism. $^{11}$

This article borrows Hart's concepts to assess the different approaches currently discussed and developed in international human rights and investment law to establish investor obligations. ${ }^{12}$ The article first develops a general framework of analysing and comparing these approaches. Subsequently, the attempts to include direct obligations of business entities in international human rights treaties are discussed. Despite earlier indications, the recent initiative to create a legally binding instrument on business and human rights will most likely not include direct obligations for business entities. Next, the article turns to developments in international investment law. After briefly contextualizing the question about investor obligations in the wider debate on investment law and human rights, the article assesses the development of investor obligations in new international investment treaties and through the interpretation and application of existing international investment agreements. Arguably, the former will not lead to binding obligations in the foreseeable future and the latter rests on methodologically questionable grounds. Consequently, the article suggests that the way forward will require domestic legislation in host and home states to establish investor obligations which can be taken into account when interpreting existing treaty clauses. It is claimed that such an endeavour may be practically more viable and methodologically sounder than a pure reliance on international investment law. The

8 HLA Hart, 'American Jurisprudence through English Eyes: The Nightmare and the Noble Dream' (1977) 11 Georgia Law Review 969, 972.

9 Hart, note 8, 971.

10 Hart, note 8, 972.

11 Hart, note 8, 978.

12 It remains of course in the eye of the beholder whether investor obligations are a nightmare or a noble dream to begin with. 
article concludes that this approach would reflect recent trends both in investment law reforms as well as the business and human rights movement, thereby establishing a pluralistic legal framework of obligations for foreign investors.

\section{A Framework for the Establishment of Investor Obligations IN INTERNATIONAL LAW}

International investment law and international human rights law are two distinct fields of international law. Even if one subscribes to the view that they may have a common root in the customary law protecting aliens, ${ }^{13}$ the two regimes rest on different legal sources, contain different legal principles and are applied and administered in different institutional settings. ${ }^{14}$ This does not exclude the possibility of overlaps in certain situations, but generally the two regimes remain separate and have distinct features. ${ }^{15}$

International investment law rests on a web of thousands of bilateral investment treaties and other treaties with investment protection provisions. ${ }^{16}$ It contains general standards of protecting foreign investors and their investment, including compensation for expropriation as well as guarantees of fair and equitable treatment and nondiscrimination of the investor. Investment treaties are applied by ad hoc tribunals established at the request of a foreign investor and based on the claim that the host state treated the investor in a manner which violates the term of the respective investment agreement.

In contrast, human rights law is enshrined in global and regional human rights treaties which contain rights of individuals and respective obligations of states to respect, protect and fulfil those human rights. International human rights treaties are applied by regional human rights courts or special bodies established on the basis of human rights treaties.

In light of the distinct nature of the two regimes, a framework to analyse the development of investor obligations should distinguish the investment and the human rights regime. Within each regime, the development could be based on a legislative approach involving the drafting of new treaties or the inclusion of new provisions in existing treaties or a judicial approach relying on the interpretation of existing treaties by international courts and tribunals. The two regimes and the two approaches can be combined in a two-by-two matrix as illustrated in Table 1.

\footnotetext{
13 Pierre-Marie Dupuy and Jorge E Viñuales, 'Human Rights and Investment Disciplines: Integration in Progress' in Marc Bungenberg et al (eds.), International Investment Law (München: C.H. Beck, 2015) 1739, 1743.

14 Moshe Hirsch, 'Investment Tribunals and Human Rights: Divergent Paths' in Pierre-Marie Dupuy, Ernst-Ulrich Petersmann and Francesco Francioni (eds.), Human Rights in International Investment Law and Arbitration (Oxford: Oxford University Press, 2009) 97, 107-110; Marc Jacob, 'Faith Betrayed: International Investment Law and Human Rights' in Rainer Hofmann and Christian Tams (eds.), International Investment Law and Its Others (Baden-Baden: Nomos, 2012) 25, 36-43.

15 Maria Fanou and Vassilis Tzevelekos, 'The Shared Territory of the ECHR and International Investment Law' in Yannick Radi (ed.), Research Handbook on Human Rights and Investment (Cheltenham: Edward Elgar, 2019), 95-102. This remains, however, contested, see James Fry, 'International Human Rights Law in Investment Arbitration: Evidence of International Law's Unity' (2007) 18 Duke Journal of Comparative \& International Law 77, 147.

16 According to UNCTAD there are 2912 Bilateral Investment Treaties (BITs), of which 2354 are in force, and 388 so-called Treaties with Investment Provisions (TIPs), of which 313 are in force, as of September 2019, https:// investmentpolicy.unctad.org/international-investment-agreements (last accessed 5 October 2019).
} 
Table 1. Four approaches to establish human rights obligations of businesses in international law

\begin{tabular}{|l|l|l|}
\hline Legal regime & Treaty-making (legislation) & $\begin{array}{l}\text { Treaty-application } \\
\text { (jurisprudence) }\end{array}$ \\
\hline $\begin{array}{l}\text { International human rights } \\
\text { law }\end{array}$ & $\begin{array}{l}\text { Establish binding obligations } \\
\text { for businesses in human } \\
\text { rights treaties }\end{array}$ & $\begin{array}{l}\text { Establish obligations of } \\
\text { business enterprises based } \\
\text { on interpretations of human } \\
\text { rights treaties by human } \\
\text { rights courts }\end{array}$ \\
\hline International investment law & $\begin{array}{l}\text { Include obligation to respect } \\
\text { human rights in investment } \\
\text { treaties }\end{array}$ & $\begin{array}{l}\text { Establish investor } \\
\text { obligations based on } \\
\text { interpretation of investment } \\
\text { agreements by investment } \\
\text { tribunals }\end{array}$ \\
\hline
\end{tabular}

As will be discussed below, three possible approaches have already some basis in actual international practice. Attempts to establish binding obligations for businesses in human rights law can be traced back to the late 1990s and have lately been again at the focus of an Intergovernmental Working Group of the Human Rights Council. Recent investment treaties have increasingly referred to corporate responsibilities including in some cases also human rights obligations. Tribunals interpreting and applying investment treaties have been asked to develop investor obligations based on investment treaties or other applicable law. However, the fourth approach, i.e., the establishment of human rights obligations of businesses on the basis of existing human rights treaties by human rights courts or treaty bodies, has not yet gained any practical relevance. ${ }^{17}$ While such an approach would not be unthinkable, it remains highly unlikely and difficult to conceptualize because human rights bodies currently only accept states as respondents and not private entities. In light of this jurisdictional limitation it is therefore not surprising that there have been no cases so far in which it has been argued by the claimants, let alone accepted by a court or treaty body in a concrete case, that an investor or business entity is directly bound by human rights obligations. This is why this approach will not be discussed further in this article. ${ }^{18}$

\footnotetext{
17 There are a number of judgements of the Inter-American Court for Human Rights relating to the context of business and human rights in which the court clearly established the state's duty to regulate investments as an element of its duty to protect, in particular Inter-American Court of Human Rights, Pueblo Indígena Kichwa de Sarayaku v Ecuador, IACtHR Series C No 245, 27 June 2012 and Inter-American Commission on Human Rights, Community of La Oroya v Peru, Petition 1473-06, 5 August 2009. However, there are no cases in which the court directly established obligations for private corporations. See also Rodrigo Polanco Lazo and Rodrigo Melta, 'Investment Arbitration and Human Rights Cases in Latin America' in Yannick Radi (ed.), Research Handbook on Human Rights and Investment (Cheltenham: Edward Elgar, 2019) 53-55 and 63-66.

18 The procedural question whether human rights courts or committees have the competence to hear claims against nonstate actors, needs to be distinguished from the substantive question if those entities have obligations under human rights law. On this, see section III below.
} 


\section{Human Rights Obligations of Business Entities in International Human Rights Law}

States are the primary duty bearers of international human rights obligations. Even though the Universal Declaration on Human Rights of 1948 contains language which suggests that the drafters assumed that individuals and 'organs of society' could also bear obligations under human rights law, ${ }^{19}$ human rights treaties do not contain any explicit obligations for individuals or business entities. ${ }^{20}$ This does not exclude the possibility to interpret human rights law in such a way that it also contains obligations for non-state actors as suggested by a number of commentators. ${ }^{21}$ However, so far no international adjudicative body or special committee established to hear cases on the basis of human rights treaties interpreted an existing treaty in this manner.

This is why the debate and practice focus on creating new norms that would explicitly establish binding obligations of business entities. This would be possible without deviating from the current model of international law, because states can create binding norms for non-state actors through international law. ${ }^{22}$ Such attempts first emerged in the international human rights context when the discussion on binding norms for multinational enterprises moved from the Commission on Transnational Corporations to the Sub-Commission on the Promotion and Protection of Human Rights Norms in 1997. ${ }^{23}$ However, the Norms on the Responsibilities of Transnational Corporations and Other Business Enterprises with Regard to Human Rights developed by the Sub-Commission in 2003 remained a draft and were not further pursued due to political opposition. ${ }^{24}$ Instead, the debate focused subsequently on various international non-binding standards establishing a corporate responsibility to respect human rights, most prominently in the UNGPs adopted by the UN Human Rights Council in $2011 .^{25}$

The idea of legally binding norms for business entities was reintroduced to the agenda of the UN human rights regime in 2014 with the establishment of the Open-ended Intergovernmental Working Group (OEIGWG) on transnational corporations and other business enterprises with respect to human rights entrusted with the mandate 'to elaborate an international legally binding instrument to regulate, in international human rights law, the

\footnotetext{
19 Universal Declaration of Human Rights 1948, Preamble. See Nadia Bernaz, Business and Human Rights (London: Routledge, 2017), 82.

20 Eric De Brabandere 'Human Rights and International Investment Law' in Rhea Hoffmann and Markus Krajewski (eds.), Research Handbook on Foreign Direct Investment (Cheltenham: Edward Elgar, 2019) 619, 621.

21 Adam McBeth, International Economic Actors and Human Rights (London: Routledge, 2010) 72-78; Arne Vandenbogaerd, Towards Shared Accountability in International Human Rights Law (Cambridge: Cambridge University Press, 2017) 274; Barnali Choudhury and Martin Petrin, Corporate Duties to the Public (Cambridge: Cambridge University Press, 2019) 208.

22 David Bilchitz, 'Corporate Obligations and a Treaty on Business and Human Rights' in Surya Deva and David Bilchitz (eds.), Building a Treaty on Business and Human Rights (Cambridge: Cambridge University Press, 2017) 185, 186.

23 Bernaz, note 19, 183.

24 On these norms, see David Weissbrodt and Muria Kruger, 'Norms on the Responsibilities of Transnational Corporations and Other Business Enterprises with Regard to Human Rights' (2003) 97 American Journal of International Law 901-922; Detlev F Vagts, 'The UN Norms for Transnational Corporations' (2003) 16 Leiden Journal of International Law 795-802 and McBeth, note 21, 252-260.

25 Report of the Special Representative of the Secretary-General on the Issue of Human Rights and Transnational Corporations and Other Business Enterprises, Guiding Principles on Business and Human Rights: Implementing the United Nations 'Protect, Respect and Remedy' Framework, UN Doc A/HRC/17/31 (21 March 2011).
} 
activities of transnational corporations and other business enterprises' ${ }^{26}$ The background for the establishment of the OEIGWG was the idea of creating binding obligations for business entities in an international human rights law instrument. Consequently, the discussions and debates in the first and second session of the OEIGWG in 2015 and 2016 focused inter alia on the scope and possible content of such obligations. ${ }^{27}$

In 2017 the Chairmanship of the OEIGWG published a paper with possible elements of a treaty on business and human rights (the 'Elements Paper'). ${ }^{28}$ It contained the possibility of obligations of transnational corporations such as the obligation to comply with all applicable laws and respect internationally recognized human rights, wherever they operate, and throughout their supply chains. Furthermore, the Elements Paper proposed that transnational corporations shall prevent the negative human rights impacts of their activities and provide redress. In addition, transnational corporations should design, adopt and implement internal policies consistent with internationally recognized human rights standards and establish effective follow-up and review mechanisms, to verify compliance throughout their operations. Finally, the Elements Paper referred to an obligation of transnational corporations to refrain from activities that would undermine the rule of law as well as governmental and other efforts to promote and ensure respect for human rights, and to use their influence in order to help promote and ensure respect for human rights. These proposals of the Elements Paper would have established significant and far-reaching binding human rights obligations for private corporations in the field of human rights. ${ }^{29}$

However, in light of the fierce opposition of many states towards such an approach, the first textual draft for a treaty published by the Chairmanship of the OEIGWG in July 2018 ('Zero Draft') did not contain any such obligations. ${ }^{30}$ Instead, the Zero Draft only focused on state obligations, including obligations to regulate economic activities of a transnational character and to provide access to judicial remedies for victims of human rights violations. For those who hoped that the treaty process would finally lead to binding international legal obligations of business entities, the Zero Draft was disappointing. ${ }^{31}$

It seems that the support for direct binding obligations for business entities in the treaty on business and human rights has not grown stronger within the international community since

26 Human Rights Council, Resolution 26/9 (2014).

27 See Carlos Lopez, 'Struggling to Take Off?: The Second Session of Intergovernmental Negotiations on a Treaty on Business and Human Rights' (2017) 2 Business and Human Rights Journal 365.

28 Open-ended Intergovernmental Working Group on transnational corporations and other business enterprises with respect to human rights, Elements for a Draft Legally Binding Instrument on transnational corporations and other business enterprises with respect to human rights, Chairmanship of the OEIGWG established by HRC Res. A/HRC/ RES/26/9, 29 September 2017, available at http://www.ohchr.org/Documents/HRBodies/HRCouncil/WGTransCorp/ Session3/LegallyBindingInstrumentTNCs_OBEs.pdf (accessed 5 October 2019).

29 Doug Cassel, 'The Third Session of the UN Intergovernmental Working Group' (2018) 3 Business and Human Rights Journal 277, 281.

30 Open-ended intergovernmental working group on transnational corporations and other business enterprises with respect human rights, Zero Draft legally binding instrument to regulate, in international human rights law, the activities of transnational corporations and other business enterprises, available at https://www.ohchr.org/Documents/HRBodies/ HRCouncil/WGTransCorp/Session3/DraftLBI.pdf (accessed 5 October 2019).

31 Nadia Bernaz, The Draft UN Treaty on Business and Human Rights: The Triumph of Realism over Idealism, available at https://www.business-humanrights.org/en/the-draft-un-treaty-on-business-and-human-rights-the-triumph-of-realismover-idealism (accessed 5 October 2019). For a more sceptical view on establishing binding obligations through a treaty, see Humberto Cantú Rivera, 'Some Remarks on the Third Session of the Business and Human Rights Treaty Process and the "Zero Draft"” (2018) 15 Revista de Direito Internacional (Brazilian Journal of International Law) 25, 29. 
the publication of the Zero Draft. In fact, the Revised Draft for the treaty published by the Chair of the OEIGWG in July $2019^{32}$ pursues the same approach as the Zero Draft concerning the question of binding obligations. While some language in the Preamble seems to be reminiscent of the idea that business entities are required to respect human rights $^{33}$, none of the operative articles of the Revised Draft proposed by the Chair contains any obligations which would be directly binding on business entities. ${ }^{34}$

In light of the two drafts, it is unlikely that the treaty-drafting process in the OEIGWG will lead to the establishment of direct obligations of business entities. At this juncture, it seems that investor obligations will not be expressly included in human rights treaties at the global level for the foreseeable future. While proponents of binding human rights norms for business entities may find this development deplorable, it may be a necessary compromise considering the current state of the debate among states. ${ }^{35}$

\section{Human Rights Obligations of InVestors in International INVESTMENT LAW}

The relationship between international investment law and human rights has been subject to debates in academia and practice for more than a decade. ${ }^{36}$ Generally, the debate manifests itself in two dimensions. The first dimension revolves around the argument that investment treaties may limit the possibilities of states to regulate economic activities in pursuance of their human rights obligations. It is often claimed that investment agreements impose a 'chilling effect' on states by restricting regulatory space necessary, inter alia to protect human rights. ${ }^{37}$ International investment agreements and arbitration practice may therefore conflict with human rights, because the latter would require certain state measures which the former would inhibit. ${ }^{38}$ For example, if

\footnotetext{
32 Open-ended intergovernmental working group on transnational corporations and other business enterprises with respect human rights, Revised Draft legally binding instrument to regulate, in international human rights law, the activities of transnational corporations and other business enterprises, available at https://www.ohchr.org/Documents/ HRBodies/HRCouncil/WGTransCorp/OEIGWG_RevisedDraft_LBI.pdf (accessed 5 October 2019).

33 'Underlining that all business enterprises, regardless of their size, sector, operational context, ownership and structure have the responsibility to respect all human rights, including by avoiding causing or contributing to adverse human rights impacts through their own activities and addressing such impacts when they occur, as well as by preventing or mitigating adverse human rights impacts that are directly linked to their operations, products or services by their business relationships'.

34 For a critique of this, see Jernej Letnar Černič, 'The 2019 Draft of the Business and Human Rights Treaty: Nothing Left to Improve?', BHRJ Blog, 6 September 2019, https://www.cambridge.org/core/blog/2019/09/06/the-2019-draft-ofthe-business-and-human-rights-treaty-nothing-left-to-improve/ (accessed 5 October 2019).

35 Marta Piazza, 'Revised Draft: Did States get a Passing Grade?', BHRJ Blog, 30 September 2019, https:// www.cambridge.org/core/blog/2019/09/30/revised-draft-did-states-get-a-passing-grade/ (accessed 5 October 2019).

36 See generally Pierre-Marie Dupuy, Ernst-Ulrich Petersmann and Francesco Francioni (eds.), Human Rights in International Investment Law and Arbitration (Oxford: Oxford University Press, 2009).

37 UNGA, Report of the Special Rapporteur of the Human Rights Council on the rights of indigenous peoples on the impact of international investment and free trade on the human rights of indigenous peoples, A/70/301, 7 August 2015, para 46.

38 Eric De Brabandere 'Human Rights and International Investment Law' in Rhea Hoffmann and Markus Krajewski (eds.), Research Handbook on Foreign Direct Investment (Cheltenham: Edward Elgar, 2019) 619; Moshe Hirsch, 'Interactions Between Investment and Non-Investment Obligations' in Peter Muchlinski et al (eds.), The Oxford Handbook of International Investment Law (Oxford: Oxford University Press, 2008) 154, 179; Bruno Simma, 'Foreign Investment Arbitration: A Place for Human Rights?' (2011) 60 International \& Comparative Law Quarterly 573,578 .
} 
investment agreements limit policy options for states to reduce the consumption of tobacco, they may have a negative effect on the state's obligation to protect the human right to health. ${ }^{39}$ Similarly, if investment agreements restrict possibilities to impose regulations on private corporations supplying drinking water, the human right to water may be negatively affected. ${ }^{40}$ In these situations, the question arises if human rights obligations of states can be used as justification of state measures and therefore as defence against claims that these measures violate investment treaty obligations. ${ }^{41}$ Another aspect in this context concerns the question of a hierarchy between international investment agreements and human rights treaties if the former conflict with obligations of the latter. ${ }^{42}$

The second dimension of the relationship between international investment law and human rights concerns human rights obligations of investors. Instead of justifying state actions based on the duty to protect, human rights would be used to assess the behaviour of investors. In the above-mentioned examples, it could be asked if the investor's behaviour that triggered the respective state action constituted a violation of the investor's own obligations under human rights law. As pointed out above, human rights treaties do not currently contain binding obligations for business entities, and this will not change in the near future. Hence, obligations of investors would need to be established in international investment agreements or through the interpretation and application of these agreements by investment tribunals.

\section{A. Obligations to Respect Human Rights in International Investment Agreements}

Incorporating investor obligations in international investment treaties constitutes an important element of the reform process of international investment law. ${ }^{43}$ Human rights obligations of investors in international investment agreements could be established through incorporating international standards such as the Organisation for

\footnotetext{
39 See, e.g., Philip Morris Brands Sàrl, Philip Morris Products S.A. and Abal Hermanos S.A. v Oriental Republic of Uruguay, ICSID Case No. ARB/10/7. On this, see Monica Feria-Tinta, 'Like Oil and Water? Human Rights in Investment Arbitration in the Wake of Philip Morris v Uruguay' (2017) 34 Journal of International Arbitration 601; Sera Mirzabegian, 'Big Tobacco v Australia: Challenges to Plain Packaging' (2019) 4 Business and Human Rights Journal 177.

40 See, e.g., Compañía de Aguas del Aconquija S.A. and Vivendi Universal S.A. v Argentine Republic, ARB/97/3; Azurix Corp. v Argentine Republic, ARB/01/12; Suez, Sociedad General de Aguas de Barcelona S.A. and Interagua Servicios Integrales de Agua S.A. v Argentine Republic, ARB/03/17; Azurix Corp. v Argentine Republic, ARB/03/30; SAUR International v Argentine Republic, ARB/04/4; Biwater Gauff (Tanzania) Limited v United Republic of Tanzania, $\mathrm{ARB} / 05 / 2$. On these cases, see Jorge E Viñuales, 'Access to Water in Foreign Investment Disputes' (2009) 21 Georgetown International Environmental Law Review 733-759; Andreas Kulick, Global Public Interest in International Investment Law (Cambridge: Cambridge University Press, 2012) 288-300; Pierre Thielbörger, The Right(s) to Water - The Multi-Level Governance of a Unique Human Right (Heidelberg: Springer, 2014); Ursula Kriebaum, 'The Right to Water Before Investment Tribunals' (2018) 1 Brill Open Law 16-36.

41 Ursula Kriebaum, 'Human Rights and International Investment Law', in Yannick Radi (ed.), Research Handbook on Human Rights and Investment (Cheltenham: Edward Elgar, 2019), 33-39; Nicolás M Perrone, 'The "Invisible" Local Communities: Foreign Investor Obligations, Inclusiveness, and the International Investment Regime' (2019) 113 AJIL Unbound 16, 18-19.

42 On how a new treaty could address this issue, see Markus Krajewski, Ensuring the Primacy of Human Rights in Trade and Investment Policies: Model Clauses for a UN Treaty on Transnational Corporations, Other Businesses and Human Rights (Brussels: CIDSE, 2017), 13-15 and 25-27.

43 UNCTAD, note $6,85$.
} 
Economic and Co-operative Development (OECD) Guidelines for Multinational Enterprises in investment agreements as binding norms, ${ }^{44}$ or through direct investor obligations. $^{45}$

\section{Direct Investor Obligations to Respect Human Rights}

The most straightforward approach to establish investor obligations in international investment law is the incorporation of norms which contain explicit duties of investors. $^{46}$ In this respect, international investment agreements could expressly require investors to respect human rights. Until recently, this option only existed in some model bilateral investment agreements which had not yet been transformed into actual agreements. ${ }^{47}$

However, on 3 December 2016 Morocco and Nigeria signed the first international investment agreement which contains a clause establishing that investors need to respect human rights. ${ }^{48}$ Even though the agreement is not yet in force, it has already attracted considerable academic and political attention. ${ }^{49}$ Article 18 para 2 of the Morocco-Nigeria Bilateral Investment Treaty (BIT) states: 'Investors and investments shall uphold human rights in the host state'. This paragraph is part of the general article entitled 'Postestablishment Investor Obligations' in that treaty, which also includes the obligation to act in accordance with core labour standards (Article 18 para 3) and the obligation not to circumvent international environmental, labour and human rights obligations of the host and/or home state (Article 18 para 4).

While it is clear that Article 18 para 2 of the Morocco-Nigeria BIT contains a direct and binding obligation as indicated by the word 'shall', ${ }^{50}$ its content is less than clear. The first ambiguity concerns the duty-bearers. Usually, duty-bearers of human rights are persons, either states and other public entities or as in the present case investors, i.e., natural and legal persons. However, it is difficult to imagine how 'investments' - property or other assets - can have legal duties in addition to investors. However, it is suggested that the

\footnotetext{
44 See, e.g., Eva van der Zee, 'Incorporating the OECD Guidelines in International Investment Agreements: Turning a Soft Law Obligation into Hard Law?' (2013) 40 Legal Issues of Economic Integration 33.

45 Barnali Choudhury, 'Spinning Straw into Gold: Incorporating the Business and Human Rights Agenda into International Investment Agreements' (2017) 38 University of Pennsylvania Journal of International Law 425, 469470; Mavluda Sattorova, 'Investor Responsibilities from a Host State Perspective: Qualitative Data and Proposals for Treaty Reform' (2019) 113 AJIL Unbound 22, 24.

46 Karsten Nowrot, The Other Side of Rights in the Processes of Constitutionalizing International Investment Law: Addressing Investors' Obligations as a New Regulatory Experiment (Hamburg: Universität Hamburg, 2018) 12.

47 See, e.g., Lise Johnson, Lisa E Sachs and Jesse Coleman, 'International Investment Agreements, 2014: A Review of Trends and New Approaches' (2015-2016) Yearbook on International Investment Law and Policy 58.

48 Text available at: https://investmentpolicy.unctad.org/international-investment-agreements/treaty-files/5409/ download (accessed 5 October 2019).

49 Tarcisio Gazzini, 'The 2016 Morocco-Nigeria BIT: An Important Contribution to the Reform of Investment Treaties', Investment Treaty News (September 2017) 3; Busola Bayo-Ojo, 'Nigeria: Morocco-Nigeria BIT: A Departure or More of the Same?', http://www.mondaq.com/Nigeria/x/765460/Inward+Foreign+Investment/ MoroccoNigeria+BIT+A+departure+or+more+of+the+same+by+Busola+BayoOjo (accessed 5 October 2019); Niccolò Zugliani, 'Human Rights in International Investment Law: The 2016 Morocco-Nigeria Bilateral Investment Treaty, (2019) 68 International \& Comparative Law Quarterly 761-770.

50 See also Nitish Monebhurrun, 'Mapping the Duties of Private Companies in International Investment Law' (2018) 15 Revista de Direito Internacional (Brazilian Journal of International Law) 50, 57-58.
} 
clause should not be interpreted in a strict literal meaning, but that it requires investors to ensure that their investments do not have any negative impacts on human rights.

Secondly, it is puzzling why the clause requires investors and investments to 'uphold' human rights. Standard human rights terminology refers to the obligation to respect, protect and fulfil human rights. It is unclear if the term 'uphold' would have a different meaning or include all three dimensions of human rights obligations. Yet, nothing in the treaty supports the view that the parties intended to deviate from the generally accepted three-dimensional set of human rights obligations. Therefore, it can be argued that 'uphold' should be interpreted to mean 'respect, protect and fulfil' human rights.

Finally, it needs to be clarified what the treaty means with the reference to 'human rights in the host state'. Does this refer to those human rights which are applicable in the host state as a matter of domestic and international law, or does it refer to all international human rights? A contextual interpretation of that clause taking paragraph 4 of Article 18 into account would suggest that at least those human rights treaties which are binding on the two state parties would be included. In addition, one could argue that as investors are obliged to follow domestic law, human rights in Article 18 para 2 of the BIT refer to those human rights which are part of the domestic law of the host state.

It has been suggested that the approach taken by Morocco and Nigeria in their BIT is part of an emerging trend in African investment treaty practice and law-making. ${ }^{51}$ For example, Article 14(2) of the Supplementary Act on Investment of the Economic Community of West African States (ECOWAS) of 2009 holds: 'Investors shall uphold human rights in the workplace and the community in which they are located. Investors shall not undertake or cause to be undertaken, acts that breach such human rights. Investors shall not manage or operate the investments in a manner that circumvents human rights obligations, labour standards as well as regional environmental and social obligations, to which the host State and/or home State are Parties'. ${ }^{52}$ Similarly, Article 19 of the African Union's Draft Pan-African Investment Code (PAIC) of $2016^{53}$ states 'Investments shall meet national and internationally accepted standards of corporate governance for the sector involved, in particular for transparency and accounting practices.' 54

Yet, despite these models, no other bilateral investment agreement or agreement with investment protection followed the approach taken by the Morocco-Nigeria BIT so far. In fact, Morocco and Nigeria themselves have not been pursuing the idea of investor obligations further: the Brazil-Morocco BIT signed on 13 June 2019 follows the

\footnotetext{
51 Makane Moïse Mbengue and Stefanie Schacherer, 'The "Africanization” of International Investment Law: The PanAfrican Investment Code and the Reform of the International Investment Regime' (2017) 18 Journal of World Investment \& Trade 414; Zugliani, note 49, 762.

52 ECOWAS, 'Supplementary Act A/SA.3/12/08 Adopting Community Rules on Investment and the Modalities for their Implementation with ECOWAS of 19 December 2008', text available at: http://investmentpolicyhub.unctad.org/ Download/TreatyFile/3266 (accessed 5 October 2019).

53 African Union Commission, Economic Affairs Department, Draft Pan-African Investment Code (December 2016), available at: https://au.int/sites/default/files/documents/32844-doc-draft_pan-african_investment_code_december_ 2016_en.pdf (accessed 5 October 2019).

54 See also W Kidane, 'Contemporary International Investment Law Trends and Africa's Dilemmas in the Draft PanAfrican Investment Code' (2018) 50 The George Washington International Law Review 523 (567).
} 
Brazilian model BIT ${ }^{55}$ and the Morocco-Republic of Congo BIT signed more than a year after the Nigeria-Morocco BIT in April 2018 does not contain any reference to investor obligations or corporate social responsibility standards. ${ }^{56}$ Nigeria has not signed any investment agreement since the signature of the Morocco-Nigeria BIT. ${ }^{57}$ The NigeriaSingapore BIT signed in 2016 shortly before the Morocco-Nigeria BIT contains no investor responsibilities either. ${ }^{58}$

However, a related approach can be found in Article 18(1) of the 2019 Model BIT of Belgium and Luxembourg. ${ }^{59}$ It requires investors to 'act in accordance with internationally accepted standards applicable to foreign investors to which the Contracting Parties are a party'. Internationally accepted standards applicable to foreign investors would seem to refer to such regimes as the UNGPs, the OECD Guidelines for Multinational Enterprises or the ILO Tripartite Declaration of Principles concerning Multinational Enterprises and Social Policy. These standards would fall into the ambit of the clause if the parties of the investment treaty would also be a 'party' to that standard. Technically though, as these standards do not constitute international treaties, they have no parties. However, the term 'party' should not be interpreted in such a strict technical manner. It seems to refer to the Member States of the relevant international organization which adopted the standard (UN, ILO and OECD) and in the case of the OECD Guidelines also to the additional 12 adhering non-OECD countries. The legal effect of a provision like Article 18(1) of the Model BIT would therefore be that voluntary, non-binding standards of conduct would be turned into legally binding norms. In short, investors would be bound by the duties enshrined in these standards.

\section{Best Endeavour and Soft Law Approaches}

The previous section showed that it is possible to include direct investor obligations in investment agreements, but states have been reluctant to implement such an approach in practice. Instead, most agreements that contain references to investor obligations employ non-binding standards including best endeavour-obligations or other hortatory language. One leading example is Article 14(2)(b) of the 2015 Brazilian Model Cooperation and Facilitation Investment Agreement. ${ }^{60}$ It reads: 'The investors and their investment shall

\footnotetext{
55 On this, see section 2 below.

56 UNCTAD, Taking Stock of IIA Reform: Recent Developments, IIA Issues Note No. 3, June 2019, p 10 and UNCTAD, WIR 2019, p 108. Text of the BIT available at: https://investmentpolicy.unctad.org/internationalinvestment-agreements/treaty-files/5809/download (accessed 5 October 2019).

57 Information and texts available at: https://investmentpolicy.unctad.org/ (accessed 5 October 2019). Morocco also signed a BIT with South Sudan on 1 February 2017. However, the text of this agreement is not (yet) publicly available.

58 Text available at: https://investmentpolicy.unctad.org/international-investment-agreements/treaty-files/5410/download (accessed 5 October 2019).

59 Text available at: https://investmentpolicy.unctad.org/international-investment-agreements/treaty-files/5854/download (accessed 5 October 2019).

60 Text available at: https://investmentpolicy.unctad.org/international-investment-agreements/treaty-files/4786/ download (accessed 5 October 2019). On the Brazilian BIT, see also Geraldo Vidigal and Beatriz Stevens, 'Brazil's New Model of Dispute Settlement for Investment: Return to the Past or Alternative for the Future?' (2018) 19 The Journal of World Investment \& Trade 475-512 and Nitish Monebhurrun, 'Novelty in International Investment Law: The Brazilian Agreement on Cooperation and Facilitation of Investments as a Different International Investment Agreement Model' (2017) 8 Journal of International Dispute Settlement 79-100.
} 
endeavour to comply with the following voluntary principles and standards for a responsible business conduct and consistent with the laws adopted by the Host State receiving the investment [...] (b) Respect the internationally recognized human rights of those involved in the companies' activities [...].' Brazil has included this clause in most of its recent investment agreements. ${ }^{61}$

The clause is noteworthy for a number of reasons. First, it is important to realize that the clause construes a binding obligation ('shall'). However, the content of that obligation is limited to the best endeavour of an investor to comply with what the clause calls 'voluntary principles and standards for a responsible business conduct'. While the clause therefore considers the standards as 'voluntary', it requires investors to at least attempt to comply with these standards. In other words, an investor that ignores these standards at all or even openly rejects them would violate this obligation. However, any failure to actually comply with the standards would not be a violation of the agreement as long as the investor can demonstrate that it tried to achieve the standard. Nevertheless, the Brazilian approach may be a step towards more binding obligations, because it is not completely within the discretion of the investor to respect human rights.

Furthermore, the clause in the Brazilian Model BIT also raises questions concerning the term 'the following voluntary principles and standards'. It is not clear what this term refers to, because the clause does not mention any specific principles and standards such as the UNGPs or the OECD Guidelines. It must be assumed that the various broad and general conduct standards listed in letters (a) to (k) of Article 14 paragraph 2 are the mentioned principles and standards. ${ }^{62}$ Yet, it should be pointed out that not all of those standards are merely 'voluntary'. For example, human rights as mentioned in Article 14 paragraph 2 letter (b) cannot be reduced to

61 Examples include Article 13(2) of the Brazil-Morocco BIT of 2019, Article 15(2) Brazil-UAE BIT of 2019, Article 15(2) of the Brazil-Guyana BIT of 2018 and Article 8.15(2) Brazil-Chile Free Trade Agreement of 2018.

62 Article 14 paragraph 2 of the Brazilian Model BIT reads in its entirety: 'The investors and their investment shall endeavour to comply with the following voluntary principles and standards for a responsible business conduct and consistent with the laws adopted by the Host State receiving the investment:

a) Contribute to the economic, social and environmental progress, aiming at achieving sustainable development;

b) Respect the internationally recognized human rights of those involved in the companies' activities;

c) Encourage local capacity building through close cooperation with the local community;

d) Encourage the creation of human capital, especially by creating employment opportunities and offering professional training to workers;

e) Refrain from seeking or accepting exemptions that are not established in the legal or regulatory framework relating to human rights, environment, health, security, work, tax system, financial incentives, or other issues;

f) Support and advocate for good corporate governance principles, and develop and apply good practices of corporate governance;

g) Develop and implement effective self-regulatory practices and management systems that foster a relationship of mutual trust between the companies and the societies in which its operations are conducted;

h) Promote the knowledge of and the adherence to, by workers, the corporate policy, through appropriate dissemination of this policy, including programs for professional training;

i) Refrain from discriminatory or disciplinary action against employees who submit grave reports to the board or, whenever appropriate, to the competent public authorities, about practices that violate the law or corporate policy;

j) Encourage, whenever possible, business associates, including service providers and outsources, to apply the principles of business conduct consistent with the principles provided for in this Article; and

k) Refrain from any undue interference in local political activities.' 
non-binding voluntary standards, because the UNGPs contain binding obligations for states and a strong normative expectation for business to adhere to the standards of corporate human rights responsibility. ${ }^{63}$

While the Brazilian approach requires investors to attempt to comply with international standards, many other investment agreements use softer language. Often, the parties suggest that investors 'should' adhere to international standards or incorporate such standards into their business models. ${ }^{64}$ For example, Article 12 of the Argentina-Qatar BIT of 2016 states '[i]nvestors operating in the territory of the host Contracting Party should make efforts to voluntarily incorporate internationally recognized standards of corporate social responsibility into their business policies and practices. ${ }^{65}$

Similarly, Article 24 of the African Union's Draft Pan-African Investment Code (PAIC) of $2016^{66}$ requires that 'the following principles should govern compliance by investors with business ethics and human rights: (a) support and respect the protection of internationally recognized human rights; (b) ensure that they are not complicit in human rights abuses; [...].' The development of investment law in Africa is still ongoing ${ }^{67}$ and it is possible that a future Investment Protocol of the African Continental Free Trade Agreement (AfCFTA) may contain stronger obligations. ${ }^{68}$

An even less strict and indirect approach does not contain direct encouragements or soft expectations of investors but requires the state parties to encourage them. Examples can be found in Article 7(2) of the 2019 Model BIT of the Netherlands ${ }^{69}$ and Article 5 paragraph 2 of Chapter 9 of the Pacific Agreement on Closer Economic Relations (PACER) Plus of $2017^{70}$ : 'The Parties reaffirm the importance of each Party encouraging enterprises operating within its territory or subject to its jurisdiction to voluntarily incorporate into their internal policies internationally recognised standards, guidelines and principles of corporate social responsibility that have been endorsed or are supported

63 For a similar critical view in this regard, see Monebhurrun, note 60, 97-98.

64 Laurence Dubin, 'Corporate Social Responsibility Clauses in Investment Treaties', Investment Treaty News, 21 December 2018, https://www.iisd.org/itn/2018/12/21/corporate-social-responsibility-clauses-in-investmenttreaties-laurence-dubin/ (accessed 5 October 2019); Laurence Dubin, 'RSE et droit des investissements, les prémisses d'une rencontré' (2018) 122 Revue générale de droit international public 867-891.

65 Text available at: https://investmentpolicy.unctad.org/international-investment-agreements/treaty-files/5383/ download (accessed 5 October 2019).

66 African Union Commission, Economic Affairs Department, Draft Pan-African Investment Code (December 2016), available at: https://au.int/sites/default/files/documents/32844-doc-draft_pan-african_investment_code_december_ 2016_en.pdf (accessed 5 October 2019).

67 Makane Moïse Mbengue and Stefanie Schacherer, 'The “Africanization” of International Investment Law: The PanAfrican Investment Code and the Reform of the International Investment Regime' (2017) 18 Journal of World Investment \& Trade 414, 434-436.

68 The AfCFTA Agreement is supposed to be supplemented by a Protocol on Investment, presumably adopted in 2021. See para 13(ii) of the Decision on the African Continental Free Trade Area (419 KB), Doc. Assembly/AU/4(XXXII). On this, see also Talkmore Chidede, 'How Can the AfCFTA Investment Protocol Advance the Realisation of the AfCFTA Objectives?' Tralac Blog, 17 May 2019, https://www.tralac.org/blog/article/14065-how-can-the-afcfta-investmentprotocol-advance-the-realisation-of-the-afcfta-objectives.html (accessed 5 October 2019).

69 Text available at: https://investmentpolicy.unctad.org/international-investment-agreements/treaty-files/5832/ download (accessed 5 October 2019).

70 Text available at: https://investmentpolicy.unctad.org/international-investment-agreements/treaty-files/5586/ download (accessed 5 October 2019). 
by that Party.' This clause only indirectly addresses investors, because it requires each state party to act first. Hence, the 'encouragement' will only materialize if and when the respective state party actually acts upon it.

The difference between a direct encouragement in the investment agreement and a reference to the obligation of the parties to encourage investors to adhere to standards of corporate responsibility may seem marginal from a substantive perspective. However, it could become relevant if applied in a concrete investor-state dispute: a tribunal which would consider the activities and the behaviour of the investor in the context of applying the investment agreement might find it easier to assess the investor's behaviour on the basis of the respective standards if they are part of the agreement itself. If the investment agreement only refers to the state party's obligation, the tribunal might have to assess first if the state party adopted a policy of encouraging the relevant standards.

\section{Obligations to Observe Host State Laws and Regulations}

Apart from creating direct legal obligations or incorporating soft law approaches, investment treaties can also contain obligations of investors to comply with the domestic law of the host state. Even though this requirement may seem redundant, because investors are bound by the laws of the host state in any case, it incorporates the respective obligations into the international legal relationship between investor and host state. This strengthens the obligations and could turn a violation of domestic law into an issue subject to a potential investor-state dispute. The requirement to observe domestic law functions therefore in a similar way as an umbrella clause in international investment agreements which incorporates domestic rights of the investor into the international investor-state relationship.

Sometimes, the reference to domestic law is linked to the idea of human rights. For example, Article 12.1 of the Indian Model BIT states that '[i]nvestors and their Investments shall be subject to and comply with the Law of the Host States. This includes, but is not limited to, [...] (v) Law relating to human rights. ${ }^{71}$ Similarly, Article 7(1) of the 2019 Model BIT of the Netherlands ${ }^{72}$ holds that '[i]nvestors and their investments shall comply with domestic laws and regulations of the host state, including laws and regulations on human rights, environmental protection and labor laws.'

It is clear that provisions like these do not establish a direct obligation of investors to adhere to international human rights law. Instead, the extent of the human rights obligations will be determined by the legislator of the host state. ${ }^{73}$ Hence, the scope and contents of those obligations would vary. It could be argued that the laws of the host state would include the legislative act incorporating human treaties into the domestic legal order in dualist systems. In this case, a reference to domestic law would also refer to

\footnotetext{
71 Text available at: https://www.mygov.in/sites/default/files/master_image/Model Text for the Indian Bilateral Investment Treaty.pdf (accessed 5 October 2019).

72 Text available at: https://investmentpolicy.unctad.org/international-investment-agreements/treaty-files/5832/ download (accessed 5 October 2019).

73 Peter Muchlinski, 'The Impact of a Business and Human Rights Treaty on Investment Law and Arbitration', in Surya Deva and David Bilchitz (eds.), Building a Treaty on Business and Human Rights (Cambridge: Cambridge University Press, 2017) 346, 350.
} 
international human rights treaties. However, such a reference could also be interpreted to refer to domestic legislation that is aimed at implementing human rights obligations into domestic law. While some states incorporate international human rights treaties into their constitutional law, others include catalogues of specific human or basic rights in their constitutions. Yet, even if human rights are part of the domestic law, they do not necessarily contain binding obligations on non-state entities. Like international human rights law, domestic human rights are often only binding on public entities. In these cases, it could be argued that provisions like the ones mentioned above refer to those elements of domestic law which aim at the protection of human rights even if they do not mention human rights specifically. For example, setting quality standards for drinking water protects the human right to health and to water specifically, even if the respective legislation is not formulated in the language of human rights. Similarly, the adoption of labour rights, wage laws and safety standards at work implement the rights associated with the human right to work.

However, even if the reference to domestic 'laws on human rights' is understood in such a broad manner, it is unclear how it relates to the general obligation of investors to adhere to relevant and applicable domestic legislation. Again, as investors are typically bound by all domestic laws of the host state, it could be asked if the reference to human rights has any added value. In any event, such a reference does not create any new substantive obligation of investors. Nevertheless, a reference to domestic laws and legislations in an investment treatment incorporates them into the international investment law realm may become relevant in a concrete dispute. The state could argue that the investor is also bound by domestic laws as a matter of international law and that this should be recognized by a tribunal assessing a concrete case.

\section{Consistency of Investment Treaty-Making and Human Rights Treaty-Making}

It should be clear from the above that states remain reluctant to include direct investor obligations in investment agreements, despite some interesting developments in newer model agreements. The academic and political attention to the approach taken by the Morocco-Nigeria BIT seems to over-estimate the willingness of the states to include binding obligations. States apparently fear that such obligations would deter investors and therefore defeat the purpose of an investment agreement which is aimed at attracting investors even if the empirical basis for assuming that investment agreements contribute to the flow of investment is questionable. Nevertheless, states increasingly address investor obligations by either incorporating best endeavour standards or references to soft law standards. This approach coincides with the reluctance of states to create binding obligations for business entities in the human rights realm. ${ }^{74}$ It is not surprising that states which are not even willing and able to incorporate binding business obligations in human rights treaties are reluctant to include binding investor obligations in investment agreements, especially as these are predominantly aimed at granting rights to investors. Both the investment regime and the human rights regime seem to rely predominantly on

74 See section III above. 
non-binding standards for investors and not on binding obligations. When it comes to binding obligations, both regimes focus on what states could and should do. However, while investment agreements typically only incorporate the obligation of investors to adhere to the laws and regulations of the host state, human rights agreements can also include obligations of home states such as the obligation to adopt binding human rights due diligence regulations. ${ }^{75}$

\section{B. Human Rights Obligations of Investors Established by Investment Tribunals}

As demonstrated above, attempts to establish express obligations for business entities in international treaties have not been successful so far. This is one of the reasons why a lot of attention has been given to developments in international investment arbitration. ${ }^{76}$ Human rights can be relevant in an investment dispute in a variety of different settings: investors themselves can claim human rights, states can rely on human rights as justifications for regulatory activities, or investors can be held responsible for violating human rights of the population of the host state. ${ }^{77}$ The latter constellation is of special interest in the current context as it could be the scenario in which investment tribunals would be able to develop obligations of investors.

At the outset, it should be realized that investment tribunals would typically only be given the opportunity to discuss human rights obligations of investors if the responding state refers to them either by arguing that the investor is not eligible for the protection of the investment agreement because it violated human rights (the 'clean hands' doctrine ${ }^{78}$ ) or by raising counter-claims to the extent this is possible. Unless states introduce these arguments or claims, an investment tribunal would not assess any possible obligations of investors, because the scope of the analysis of a tribunal is usually defined and limited by what the parties argue, and which claims they make. In this context, it is worth noting that states have generally been reluctant to raise such counter-claims in investment arbitration proceedings. $^{79}$

Generally, investor obligations could be developed by investment tribunals on three legal grounds. First, tribunals could use references to other applicable law in an investment treaty and develop obligations based on human rights treaties or general international human rights law applicable between the parties of the investment agreement. This approach was adopted by the Urbaser tribunal. ${ }^{80}$ Second, an

\footnotetext{
75 See Committee on Economic, Social and Cultural Rights, General Comment No. 24 (2017) on State obligations under the International Covenant on Economic, Social and Cultural Rights in the context of business activities, 10 August 2017, E/C.12/GC/24, para 25.

76 See Silvia Steininger, 'What's Human Rights Got To Do With It? An Empirical Analysis of Human Rights References in Investment Arbitration' (2017) 30 Leiden Journal of International Law 33 and Vivian Kube and EU Petersmann, 'Human Rights Law in International Investment Arbitration' (2016) 11 Asian Journal of WTO \& International Health Law \& Policy 65.

77 Kriebaum, note 41, 18.

78 Kriebaum, note 41, 25.

79 Jean Ho, 'The Creation of Elusive Investor Responsibility' 113 (2019) AJIL Unbound 10-12.

80 Urbaser S.A. and Consorcio de Aguas Bilbao Bizkaia, Bilbao Biskaia Ur Partuergoa v The Argentine Republic, ICSID Case No. ARB/07/26, Award (8 December 2016).
} 
investment tribunal could incorporate human rights obligations of investors as part of an interpretation and application of certain provisions of the investment treaty. Evidence of this method can be found in the Separate Opinion in Bear Creek. ${ }^{81}$ Third, tribunals could rely on specific references to human rights obligations in the applicable investment agreement. However, as seen above, so far investment agreements do not include specific human rights obligations of investors, which means that tribunals would have no reliable basis in the language of the agreements. As a consequence, they might have to rely on other clauses containing investor obligations. This was hinted at in the Aven dispute. ${ }^{82}$

\section{Human Rights Obligations of Investors as Part of General Human Rights Law: Urbaser $v$ Argentina}

The first investment tribunal which accepted the idea that investors have human rights obligations was the ICSID tribunal in the matter of Urbaser $v$ Argentina which rendered its award on 8 December $2016 .{ }^{83}$ The case concerned a concession for water and sewage services granted to a company established by Urbaser. During the Argentinian financial crisis between 1998 and 2001, the project ran into difficulties and the concession was terminated. ${ }^{84}$ Unlike in previous cases in which Argentina - although reluctantly - referred to its obligations under human rights law, especially the right to water, to defend its measures, ${ }^{85}$ Argentina filed a counterclaim in Urbaser based on the investor's alleged failure to provide the necessary investment into the water concession. According to Argentina this constituted a violation of the investor's 'commitments and its obligations under international law based on the human right to water'. ${ }^{86}$

After determining that the claim fell within its jurisdiction, the tribunal held that international human rights were part of the applicable law in the dispute because the relevant BIT included a reference to 'general principles of international law' ${ }^{87}$ The tribunal therefore developed its arguments on the basis of general human rights law and not on the specifics of the applicable investment treaty which did not expressly refer to any investor obligations or standards of corporate social responsibility. ${ }^{88}$

\footnotetext{
81 Bear Creek Mining Corporation v Republic of Perú (ICSID Case No. ARB/14/21), Award of 30 November 2017. 82 David R Aven and Others $v$ Republic of Costa Rica, ICSID Case No. UNCT/15/3, Final Award, 18 September 2018.

83 Urbaser S.A. and Consorcio de Aguas Bilbao Bizkaia, Bilbao Biskaia Ur Partuergoa $v$ The Argentine Republic, ICSID Case No. ARB/07/26, Award (8 December 2016). For an analysis, see Jarrod Hepburn, 'In a First, BIT Tribunal Finds that it has Jurisdiction to Hear a Host State's Counterclaim Related to Investor's Alleged Violation of International Human Rights Obligations', Investment Arbitration Reporter, 12 January 2017, available at: https:/www.iareporter.com/articles/in-a-firstbit-tribunal-finds-that-it-has-jurisdiction-to-hear-a-host-states-counterclaim-related-to-investors-alleged-violation-ofinternational-human-rights-obligations (accessed 5 October 2019) and Monica Feria-Tinta, 'Like Oil and Water? Human Rights in Investment Arbitration in the Wake of Philip Morris v Uruguay' (2017) 34 Journal of International Arbitration 601, 625-628. It seems to be a historic coincidence that the Urbaser Award was handed down within a week of the conclusion of the Morocco-Nigeria BIT; see section IV.A.1 above.

84 Urbaser $v$ Argentina, note 80, para 34.

85 See, e.g., Suez et al $v$ The Argentine Republic, ICSID Case No. ARB/03/19, Decision on Liability (30 July 2010), [252]; SAUR International S.A. v The Argentine Republic, ICSID Case No. ARB/04/4, Decision on Jurisdiction and Liability (6 June 2012), para 328.

86 Urbaser v Argentina, note 80, para 37.

87 Urbaser v Argentina, note 80, para 1192.

88 Nowrot, note 46, 23.
} 
The tribunal began its reasoning by stating that the existence of human rights obligations of investors could not be categorically dismissed based on the fact that they are not subjects of international law. ${ }^{89}$ Indeed, the existence of investment treaties indicates that corporations can be partial subjects of public international law. However, this does not establish which obligations they have. The tribunal therefore based its finding on the growing importance of corporate social responsibility standards. ${ }^{90}$ Acknowledging that those standards alone cannot provide a legal basis for human rights obligations of private companies, the tribunal turned to international human rights instruments. The tribunal's first argument concerned the Universal Declaration of Human Rights (UDHR), in particular Article 30 of the UDHR, which provides that the UDHR may not be interpreted as allowing a state, group or person to destroy the rights and freedoms enshrined therein. According to the tribunal, this provision indicates that private entities can also be bound by human rights in general. ${ }^{91}$ The tribunal also pointed to Article 5 of the International Covenant on Civil and Political Rights (ICCPR), which is comparable to Article 30 of the UDHR. ${ }^{92}$ The tribunal concluded that these provisions show that the right of an individual is complemented by an obligation by public and private entities 'not to engage in an activity which is aimed at destroying those rights' ${ }^{93}$

Concerning the specific question of whether the claimant was bound by an international law obligation to provide the people living in the area of the concession with drinking water and sanitation services, the tribunal pointed out that the contractual obligation of Urbaser to provide water based on the concession would not include an international legal obligation of the investor. ${ }^{94}$ The tribunal also recalled the state's obligations in the context of the human right to water which 'entails an obligation of compliance on the part of the State, but it does not contain an obligation for performance on part of any company providing the contractually required service'. ${ }^{95}$ Arguing that investor obligations would have to be distinct from the State's responsibility to serve its population with drinking water and sewage services, the tribunal held that Urbaser was not under such an obligation and therefore dismissed the counter-claim.

The determination of the tribunal and its legal reasoning have already led to number of academic comments. Some have questioned the doctrinal support for the broad claims concerning the idea of human rights obligations of corporations, ${ }^{96}$ while others have argued that the practical impact of the approach taken by the tribunal may be minimal because the standards set by it for an investor's duty to actually perform certain services or activities to discharge human rights obligations will usually not be met. ${ }^{97}$ Nevertheless, it

\footnotetext{
Urbaser v Argentina, note 80, para 1194.

Urbaser v Argentina, note 80, paras 1195-1199.

Urbaser v Argentina, note 80, para 1196.

Urbaser v Argentina, note 80, paras 1197-1199.

Urbaser v Argentina, note 80, para 1199.

Urbaser v Argentina, note 80, para 1206.

Urbaser v Argentina, note 80, para 1208.

96 Edward Guntrip, 'Urbaser v Argentina: The Origins of a Host State Human Rights Counterclaim in ICSID Arbitration?', EJIL: Talk!, 10 February 2017, available at: https://www.ejiltalk.org/urbaser-v-argentina-the-origins-ofa-host-state-human-rights-counterclaim-in-icsid-arbitration/ (accessed 5 October 2019); De Brabandere, note 40.

97 Kevin Crow and Lina Lorenzoni Escobar, 'International Corporate Obligations, Human Rights, and the Urbaser Standard: Breaking New Ground?' (2018) 35 Boston University International Law Journal 87, 116-117.
} 
has also been pointed out that the tribunal's approach may lead the way to future cases in which investors could be held liable for violations of human rights. ${ }^{98}$

Regardless of its imminent practical impact, the tribunal's approach raises important conceptual questions. In particular, the tribunal's interpretation of Article 30 of the UDHR and Article 5 of the ICCPR is not based on the conventional understanding of human rights. Both provisions can be used as context when interpreting specific clauses of the human rights instruments, but they do not address the question of potential dutybearers under the relevant international instruments. ${ }^{99}$ To substantiate the claim that the UDHR 'may also address multinational companies', the tribunal referred to an article by Louis Henkin, ${ }^{100}$ who argued that the UDHR applies to everyone. Henkin relied on an the Preamble of the UDHR which states that 'every individual and every organ of society, [...] shall strive [...] by progressive measures, national and international, to secure their universal and effective recognition and observance'. ${ }^{101}$ Apart from the question if a Preamble can establish any binding effects, it is also doubtful if this sentence creates a binding obligation of individuals and companies to human rights as it only refers to an obligation to 'strive [...] to secure universal and effective recognition and observance'. ${ }^{102}$ Furthermore, the tribunal provides no reference to existing standards of interpretation (textual, contextual or object and purpose of human rights treaties) nor does it suggest any case law which might lead into the direction of human rights obligations for private entities. The tribunal could, for example, have asked if the existence of international standards and domestic laws on corporate responsibility leads to customary investor obligations.

While many human rights activists and critics of the current system of international law may welcome the fact that an investment tribunal held that investors are - at least in principle - bound by human rights obligations, the reasoning in Urbaser is more problematic than it seems. The tribunal not only erroneously held that Article 30 of the UDHR and Article 5 of the ICCPR contain a legal basis of human rights obligations of individuals and companies, it also made some confusing statements about the content of the right to water. It is unclear if the tribunal reduced the right to water to the dimension of the duty to fulfil as it pointed out that it is the state's duty to 'serve its population with drinking water'. ${ }^{103}$ Furthermore, the assertion that a state is obliged to provide the citizen with water while the investor is not, suggests that the human rights obligations of investors are different from the state obligations. Yet, if there is a human right obligation to provide water to the citizens and if the investor is bound by human rights it is not convincing that the investor would not be bound by such an obligation as well. In

\footnotetext{
98 Naomi Briercliffe, 'Holding Investors to Account for Human Rights Violations Through Counterclaims in Investment Treaty Arbitration', Allen \& Overy, 30 January 2017, available at: http://www.allenovery.com/publications/en-gb/Pages/ Holding-investors-to-account-for-human-rights-violations-through-counterclaims-in-investment-treaty-arbitration.aspx (accessed 5 October 2019).

99 Guntrip, note 96.

100 Louis Henkin, 'The Universal Declaration at 50 and the Challenge of Global Markets' (1999) 25 Brooklyn Journal of International Law 17. See Urbaser v Argentina, note 80, para 1196.

101 Henkin, note 100, 25.

102 For a critical reflection, see also De Brabandere, note 38.

103 Urbaser v Argentina, note 80, para 1208.
} 
sum, the tribunal's reasoning does not reflect the current state of human rights law. So far, there have been no other arbitral awards following the idea of investor obligations based on the Urbaser approach. ${ }^{104}$

\section{Respecting Human Rights as Obligation to Reduce Damage: Separate Opinion of Philippe Sands in Bear Creek v Peru}

Another approach to develop human rights obligations relevant in an investment case was adopted in the separate opinion of Philippe Sands in Bear Creek v Peru of 30 November 2017. ${ }^{105}$ The case concerned a Canadian mining company seeking to invest in a Peruvian silver mine. The tribunal unanimously decided that Peru's revocation of a previously granted permit necessary to operate the mine amounted to an indirect expropriation. The tribunal therefore awarded Bear Creek compensation for its respective losses.

However, arbitrator Philippe Sands was of the opinion that certain activities of the investor, especially its role in causing social unrest in the area of the project, should have been taken into account when calculating the amount of the compensation. Sands referred to ILO Convention No. 169 concerning Indigenous and Tribal Peoples in Independent Countries, which is generally accepted as part of human rights law. ${ }^{106}$ Sands conceded that the obligation to implement ILO Convention 169 falls on states and not on private parties. Yet, he also stated that 'the fact that the Convention may not impose obligations directly on a private foreign investor as such does not, however, mean that it is without significance or legal effects for them'. This statement is associated with a specific reference to the Urbaser tribunal. ${ }^{107}$ Sands went on to argue that ILO Convention 169 was applicable in the case at hand and that the investor was obliged to adhere to the requirements enshrined in that convention. Adhering to those rules would in turn have also reduced its own damage. ${ }^{108}$ As the investor had not obtained a 'social licence' to operate by consulting and cooperating with the indigenous peoples affected by the project, it contributed to the failure of the project according to Sands. ${ }^{109}$

While relying on the reasoning of the Urbaser tribunal, the separate opinion of Philippe Sands does not seem to share the conclusion that private parties could have direct obligations based on human rights law. Instead, Sands argues that investors are obliged to adhere to human rights in particular, in order to minimize any potential damages which the investors could suffer. This approach seems less burdensome on investors but may prove more powerful than the Urbaser approach due to its practical

\footnotetext{
104 UNCTAD, Review of ISDS Decisions in 2018: Selected IIA Reform Issues, IIA Issues Note No. 4, July 2019, 22.

105 Bear Creek Mining Corporation v Republic of Perú (ICSID Case No. ARB/14/21), Award of 30 November 2017, Separate Opinion of Philippe Sands. For an analysis, see also Jarrod Hepburn, 'Tribunal Rejects DCF Approach in Bear Creek Case; Dissenter sees ILO Convention on Indigenous and Tribal Peoples as Imposing Obligations in Context of Miner's ICSID Claim', Investment Arbitration Reporter, 4 December 2017, available at: https://www.iareporter.com/ articles/tribunal-rejects-dcf-approach-in-bear-creek-case-dissenter-sees-ilo-convention-on-indigenous-and-tribalpeoples-as-imposing-obligations-in-context-of-miners-icsid-claim/ (accessed 5 October 2019).

106 Bear Creek v Peru, Separate Opinion of Philippe Sands, note 105, para 7.

107 Bear Creek v Peru, Separate Opinion of Philippe Sands, note 105, para 10.

108 Bear Creek v Peru, Separate Opinion of Philippe Sands, note 105, para 11.

109 Bear Creek v Peru, Separate Opinion of Philippe Sands, note 105, para 38.
} 
effects. First, the approach taken by Sands does not require the responding state to actually file a counter-claim. Instead it would be sufficient for the state to allege that the investor did not adhere to the requirements of international human rights law. Second, taking human rights violations of an investor into account when determining the amount of the damages could have a potentially larger effect on investors than theoretical speculations about the nature of their human rights obligations, because the reduction of damages could have direct effects on investor behaviour.

However, it should also be noted that the assessment of the conduct of an investor would be better suited in the merits part of an award and less so as part of the calculation of the damages. Yet, in the absence of enforceable obligations of the investor enshrined in the investment agreement, the damages stage may be the only opportunity to assess the conduct of the investor in this regard.

\section{Investors' Obligations Based on Host State Regulations or erga omnes Norms: Aven v Costa Rica}

The second tribunal decision which referred to the Urbaser approach was the award in David R Aven and Others $v$ Costa Rica of 18 September 2018, a case based on the investment chapter in the Dominican Republic-Central America Free Trade Agreement (DR-CAFTA). ${ }^{110}$ The case concerned a number of investors who intended to develop a tourism project in Costa Rica which was terminated by the government of Costa Rica because of environmental problems of the project. After the oral hearings, Costa Rica filed a counter-claim against the investors arguing that they violated certain environmental regulations which were part of the laws of the host state.

After establishing its jurisdiction on the counter-claim, the tribunal first addressed the question of whether investors could have obligations in international (investment) law. Citing Urbaser, the Aven tribunal also stated that investors could become subjects of international law. It then argued that this is particularly the case "when it comes to rights and obligations that are the concern of all States, as it happens in the protection of the environment. ${ }^{, 11}$ In this context the tribunal referred to the idea of erga omnes norms, i.e., norms that contain rights and obligations of all states. Next, the tribunal recalled the provisions of DR-CAFTA, which required investors to abide by and comply with the measures taken by the host State to protect the environment. Based on this the tribunal stated: 'There are no substantive reasons to exempt foreign investor of the scope of claims for breaching obligations under Article 10 Section A DR-CAFTA, particularly in the field of environmental law.' 112

Yet, the tribunal did not assess the counter-claim further based on formal reasons. The tribunal pointed out that the applicable arbitration rules required Costa Rica to specify its claims. However, Costa Rica only made a general reference to environmental damages in the project site and attributed them to activities of the investors. Costa Rica also failed to

\footnotetext{
110 David R Aven and Others $v$ Republic of Costa Rica, ICSID Case No. UNCT/15/3, Final Award, 18 September 2018.

111 Aven $v$ Costa Rica, note 110, para 738

112 Aven v Costa Rica, note 110, para 739.
} 
suggest facts supporting the claims and did not specify the relief sought. As a consequence, the tribunal dismissed the counter-claim without making any further comments on investor obligations. ${ }^{113}$

In light of the procedural 'way-out', the tribunal did not discuss the legal basis for investor obligations further. Based on the tribunal's arguments, two interpretations are possible: either the tribunal derives investor obligations from all erga omnes norms because they are binding on all subjects of international law, or the tribunal refers to the obligations of investors under domestic law. While the approach using erga omnes norms would only cover very fundamental human rights such as the prohibition of torture and slavery or other fundamental human rights to the extent they are part of jus cogens, the approach taking domestic law into consideration would not establish any independent obligations of investors.

\section{Human Rights Jurisprudence of Investment Tribunals: A Nightmare or a Noble Dream?}

Applying the allegory of the nightmare and the noble dream to the reasoning of the investment tribunals discussed above does not seem to stretch the reference to Hart too far. Investment lawyers have long accepted that tribunals enjoy a wide margin of discretion when applying broad treaty terms such as 'fair and equitable treatment' or 'tantamount to an expropriation'. Yet, when does a tribunal step over the fine line between treaty interpretation and a 'legally uncontrolled act of law making'? ${ }^{114}$ Many investment lawyers and conventional legal scholars would probably argue that when the Urbaser tribunal decided that human rights would also include obligations for investors it crossed this line and engaged in law-making. The arbitrators sitting on the tribunal would of course rebut such claims and argue that they were applying the applicable law to the case and nothing else. ${ }^{115}$

In light of the different approaches of Urbaser, the separate opinion in Bear Creek and Aven, it is currently unclear and unpredictable if and how tribunals will revisit the question of investors' obligations. It also seems problematic if investment tribunals develop new interpretations of human rights law in this context which are not compatible with the jurisprudence of the regional human rights courts or the jurisprudence of the treaty bodies established in international human rights conventions. In fact, many observers are of the view that the international investment regime is not the appropriate forum to apply human rights and to further develop the idea of human rights obligations of investors, because arbitrators may not have sufficient expertise or because investment treaties only allow limited reference to human rights. This is why it has been argued that an investment tribunal which hears cases involving

\footnotetext{
113 Aven v Costa Rica, note 110, para 745.

114 Hart, note 8, 974.

115 See the reaction by the tribunal's president, Professor Andreas Bucher, to the blog contribution by Edward Guntrip (above note 92) in which Bucher claims that Article 30 of the UDHR and Article 5 of the ICCPR support the tribunal's approach and that Guntrip reads these provisions 'in the wrong way', available at: https://www.ejiltalk.org/urbaser-vargentina-the-origins-of-a-host-state-human-rights-counterclaim-in-icsid-arbitration/ (accessed 5 October 2019).
} 
human rights violations should include arbitrators with experience in human rights or should allow amicus curiae providing the necessary knowledge.

This leads to the question of whether treaty reforms might not be the better way to establish such obligations. Based on clear treaty obligations such as the ones contained in the new Morocco-Nigeria BIT, investment tribunals could interpret and apply existing treaty provisions and not engage in legally uncontrolled acts of law-making. However, this would require that such obligations are established in a sufficiently clear and precise manner. Yet, as seen above, a mere reference to human rights is not sufficient. Indeed, the current state of investment treaties and the proposed treaty on business and human rights do not seem to provide the necessary level of precision and clarity.

\section{Moving Forward and Conclusion: Neither Nightmare nor Noble Dream - Towards a Pluralistic Law of Investor and Business Obligations Concerning Human Rights}

The preceding analysis reveals a sobering result: it cannot be assumed that a new human rights treaty will contain directly binding obligations for business entities. Similarly, recent treaty-making practice in investment law also does not seem to move towards including clear and precise binding human rights obligations for investors. Finally, investment tribunals remain extremely reluctant to develop such obligations on the basis of existing international law. If they consider such approaches, the doctrinal basis is not clear. As a consequence, it seems unlikely that investor obligations to respect human rights will emerge in the foreseeable future in international treaty-making or treaty-application. For the time being, international human rights lawyers and international investment lawyers will have to accept that the noble dream of courts and tribunals applying clear, precise and comprehensive international obligations of investors will not become reality. This may be disappointing to observers who hoped that investor obligations at the international level would bypass the lacunae of domestic legislation and the gaps in its application.

However, a short cut leaving the domestic laws aside is not in sight and may not even be the most appropriate approach. Instead, human rights treaties and investment agreements should focus more on domestic legislation, such as the recently adopted human rights due diligence laws in the UK (Modern Slavery Act), France (Loi de Vigilance) and the Netherlands (Wet Zorplicht Kinderarbeid). In this context, it is interesting to note that the Revised Draft of a Legally Binding Instrument for Business and Human Rights contains obligations of states to regulate businesses in the interest of protecting human rights. ${ }^{116}$ At the same time, investment treaties incorporate references to domestic laws and may even oblige the states to effectively regulate businesses in a domestic and international setting. If relevant domestic laws are then incorporated into an investment treaty with the aim to allow a state to either base a counter-claim on the non-compliance of a domestic law by the investor or use such non-compliance to reduce the amount of the

116 Revised Draft, note 32, Article 5.1. 
damages, international investment law and tribunals may indirectly contribute to the establishment of human rights obligations of investors. Finally, states should increasingly refer to international standards of investor responsibilities in their investment treaties. This would the allow investment tribunals to rely on standards such as the UNGPs or the OECD Guidelines when interpreting and applying the terms of investment agreements.

The emerging pluralistic regime of investor obligations consisting of domestic legislation, international soft law standards and binding international treaty norms could form the basis of a web of clear and effective provisions establishing investor responsibilities on safe legal grounds. Whether such a regime contributes to a process of global constitutionalization ${ }^{117}$ remains to be seen. From a more practical perspective, it may nevertheless lead to more corporate accountability while sparing us nightmares of unclear legal developments in the future, and bringing us closer to a noble dream of a fair regulation of corporate accountability.

117 Nowrot, note 46, 32. 